\title{
Assessment of Unemployment in Dire Dawa Administration: Trends and Current Conditions
}

\author{
Belay Felek Alemu \\ MA in Development Management, Lecturer at Dire Dawa University
}

\begin{abstract}
In Ethiopia, urban unemployment is one of the socio-economic problems of urban population including Dire Dawa Administration where significant number of population is suffering from. According to the CSA (2018) employment- unemployment statistical survey report, the urban unemployment rate in Dire Dawa Administration is 25.3 percent. The unemployment rate among females is higher than males which accounts 33.5 percent and 17.6 percent respectively. The main purpose of this study is to assess the urban unemployment in Dire Dawa Administration. The study employs the annual statistical report of urban employment- unemployment survey (conducted from June, 2018 to July, 2018) by Ethiopian Central Statistics Agency. The study reveals that the rate of urban unemployment in Dire Dawa Administration is the highest in Ethiopia and far from the national unemployment rate which 19.0 percent. The survey report was supported with interview of individuals working in Dire Dawa economic bureau to triangulate the collected data.The unemployed population wants to work any available job to relief from their family assistance and support themselves and their families. Surprisingly, more than one third of unemployed population want to establish their own business, though still they did not do because of different constraints mainly shortage of finance, lack of training and finance and lack of place of working. Besides, the illiterate and trained urban population is more unemployed than that of the illiterate one which implies education doesn't guarantee for employment. Therefore, the Dire Dawa administration should consider this problem and take a serious measure to minimize the unemployed population. The administration should focus on labour-intensive investments that can employ huge man-power at a time. Besides the government should create suitable working environments for those who want to establish their own business including provision of financial credit without any collateral, working place and continuous training on entrepreneurship concepts with the collaboration of nearby higher institutions.
\end{abstract}

Keywords: Urban, unemployment, Ethiopian, CSA, job opportunity.

DOI: $10.7176 / \mathrm{EJBM} / 12-4-03$

Publication date: February $29^{\text {th }} 2020$

\section{Introduction}

Unemployment is one of the several socio-economic problems prevailing in virtually all countries of the world. It has been one of the several features of the urban phenomenon in many countries though some countries have suffered the worse rate of unemployment than others (B. Paul, 2005 and F. Nazir, M. A., et al, 2009). The problem has a serious effect not only on the living standards of the people but also on the socio-economic status of a nation (F.Nazir, M.A., et al). Coupled with population growth and increased poverty, it has a significant impact on growth and development at large. It causes a waste of economic resources such as the productive labor force and affects the long run growth potential of an economy. Unemployment gives rise to private and social problems in the society such as increased crimes, suicides, poverty, alcoholism and prostitution (Rafik et al., 2010 and Eita and Ashipala, 2010).Today, in Ethiopia, the problem of unemployment is a central concern of development and more recently the discussion has focused on unemployment in urban sectors. Many urban centers in Ethiopia are challenged by high rates of unemployment. Moreover, despite the huge unemployed labor force, urban centers of these nations experience high rate of rural-to-urban migration, exacerbating the unemployment problem of urban areas.

According to the CSA (2018) employment- unemployment statistical report, the rate of unemployment in the current status approach for urban areas of the country is 19.1 percent and the rate of unemployment for youth is 25.3 percent. At national level, Dire Dawa Administration has the highest rate of unemployment which accounts 25.3 percent.

\section{Statement of the Problem}

One of the central elements of Ethiopia's developmental challenge is unemployment and the inefficient labor market of urban areas. Ethiopia has one of the fastest growing urban populations in Africa with an urbanization rate of approximately 4 percent per annum (MUDC, 2013). It is estimated that more than 18 million people are residing in urban areas (CSA, 2018). Urban population growth is not only the feature of Addis Ababa, the capital, but is also of numerous secondary cities like Dire Dawa, Adama, Bahir Dar, etc. This high rate of urbanization places Ethiopia's urban centers under great stress mainly unemployment. Despite some improvements in recent years, a high level of unemployment continues to be a serious social problem and major policy challenge facing 
urban Ethiopia (Marta, K. 2012). The majority of the researches that have been done so far tends to concentrate on the incidence of unemployment at country level (aggregate of rural and urban) or in specific population categories, usually urban youth or women unemployment (Getenet, A. 2003, P. Serneels, 2004, N.H., Broussard and Mesfin, M., 2012). Others attempt to deal the issue of unemployment at national urban level integrating it with labor market and efforts and challenges of employment creation. Hence, it is rare to find recent studies on unemployment problem in a particular urban area like Drie Dawa (Tegegn, G., 2012). The argument, here is that for the better understanding of urban unemployment in Dire Dawa Administration and for comprehensive actions aimed at improving the problem it is better to have a look at the current urban unemployment of the city. Therefore, this study tries to give a brief insight into current unemployment situation of city; the response to it from both demand and supply side of the labor market and challenges related to employment creation.

\section{General objective}

The general objective of this study is to assess the major challenges of urban unemployment in Dire Dawa Administration.

\section{Specific Objectives}

Under the umbrella of general objective, the study has the following specific objectives:

1) To identify the challenges that deters employment creation in Dire Dawa Administration.

2) To examine the characteristics of urban unemployment in Dire Dawa Administration.

3) To suggest possible policy interventions to improve the employability of urban unemployed population in Dire Dawa Administration.

\section{Review of literature}

\section{Overview of unemployment in Ethiopian}

The labor market, like any other markets, has both supply and demand sides. The supply side, also called the labor force or the economically active population, has two components: the employed and the unemployed (Hussmanns, 1989). The demand side on the other hand consists of jobs (filled posts) and job vacancies (unfilled posts).

According to Olsson (2009), since labor is not a "normal" good, we do not have a condition where labor demand equals labor supply at equilibrium wage rate. The prevailing situation in countries around the world is instead the demand for labor is less than the supply due to the higher than equilibrium wage rate and hence there is an excess supply of labor. This gap between the supply and the demand for labor is referred to as unemployment.

The International Labor Organization (ILO) defines the unemployed as numbers of economically active population who are without work but available for and seeking work, including people who have lost their jobs and those who have voluntarily left work (WB, 2007).

\section{Causes of Unemployment}

The causes of unemployment are among the extensively debated issues by economists. Keynesian economics stresses on the inadequate aggregate demand in the economy as the major cause. Real wage rigidities and/or real interest rates cause low output and high unemployment. Real wage rigidity, "the failure of wages to adjust until labor supply equals labor demand" according to Mankiw (2002), can cause unemployment.

Studies from Ethiopia indicate that the potential causes of unemployment in urban Ethiopia include increasing number of youth labor force, the rising internal migration, literacy rate, poor to modest macroeconomic performance, low level of job creation and low level of aggregate demand in the economy (Getinet, 2003; WB, 2007). Kingdon and Knight (2004) show that unemployment in South Africa is determined by education, race, age, gender, home ownership and location among others. The study by Echebiri (2005), finds that unemployment is influenced by age, marital status, dependency ratio, education, current income and employment preference (paid or self employment). Alhawarin and Kreishan (2010) also indicate that age, gender, marital status, region, work experience and educational level are the major determinants of unemployment in Jordan.

In nutshell, youth unemployment is the outcome of different socio-economic and demographic factors at macro and micro level. The micro level factors are directly associated to individuals' demographic and socioeconomic attributes while the macro level factors are related to the national issues (Toit, 2003).

\section{Costs of Unemployment}

Unemployment comes up with costs. According to Feldstein (1997), one who wants to analyze the costs of unemployment should start by disaggregation. The costs of unemployment can be classified broadly as private 
and social. The private costs of unemployment are those costs borne by the unemployed themselves. The social costs on the other hand refer to those costs to the nation at large and can be the cumulative result of private costs. In this approach, the cost of unemployment can be seen as the opportunity cost of unemployment to the nation i.e., the cost is the national income forgone (Feldstein, 1997 and Haile, 2003).

Unemployment results in a waste of economic resources such as the productive labor force and thereby affect the long run growth potential of the economy. It gives rise to increased crimes, suicides, poverty rates, alcoholism and prostitution (Rafik et al., 2010 and Eita et al, 2010. These evils in turn come up with a cost and channel resources to their prevention which rather could have been used for other developmental purposes. Unemployment may also have a scary effect. Previous spell in unemployment has a discouraging effect on future participation in the labor force, earnings and welfare in general (Haile, 2003). Children are affected by the unemployment situation of their parents. According to Dao and Longani (2010), children of jobless parents tend to perform less in their education in the short run. In the long run, a parent's lost income due to unemployment reduces the child's earning prospect. Unemployment has an adverse effect on health and mortality via its economic, social and psychological effect on the unemployed.

\section{Overview of labor market in Ethiopia}

According to the central statistical agency of the Employment and Unemployment Survey, the total urban population of the country is estimated to be to be $18,773,035$ as of June 2018. One of the effects of such large urban population is increment in the size of the labor force. The sizes of the economically active population of the urban parts of the country in current status approaches are estimated to be 9,289,150 persons with activity rates of 62.0 percent.

According to MoLSA (2009), employment generation has two important dimensions - the demand and supply side of job creation. The first dimension (the demand side of job creation) refers to the ability of the economy to create jobs for various skill categories as per the requirement of the economy. The second dimension (the supply side of job creation) deals with whether or not the skill levels of available pool of persons match with the type of skill that the economy requires. Besides, there is a third dimension (i.e. labor market institutions) that relates to the governance of labor market relations and labor market services.

The existing institutions and legal entities mainly concern the formal and wage employment sector. Five year development plans are the main guidelines of government policy in Ethiopia. They outline the overall strategic priorities and policies of the government. The country's development plans emphasize creating employment and income-earning opportunities in the modern sector, the informal sector, and on farms.

Unemployment and underemployment are targeted with special attention given to youth and women. The 2005/6-2009/10 plan, a Plan for Accelerated and Sustained Development to End Poverty (PASDEP), explicitly acknowledged the issue of the labor market and unemployment, particularly youth unemployment. The plan focused on job creation through private sector participation, with particular emphasis given to Micro and Small Enterprises (MSE), based on their potential to create employment opportunities. The plan also addressed improving the quality of education and integrating Technical and Vocational Education and Training (TVET) with the job requirements of the economy, which were identified as key problems leading to rising unemployment particularly in urban areas. Other solutions included special efforts to provide skills training to the unemployed and public works employment interventions (FDREb, 2004; MoFED, 2006). Technical and vocational training in Ethiopia offers programs that target those students who do not progress to higher levels of education. The aim is to provide the students with skills and competencies for engagement in wage employment or self-employment (MOE, 2006).

The five-year development plan 2010/11-2014/5, the Growth and Transformation Plan (GTP), does not directly address the issue of youth unemployment, but rather implicitly through improved performance of the various sectors in the economy. The plan addresses the economic and social challenges faced by women and youth. Private sector development, particularly MSEs, continue to receive special attention as potential employment hubs and poverty reduction mechanisms. The plan emphasizes tailoring TVET programs with the demands of the economy and to continue to scale up MSE expansion as strategies tackling unemployment in the country (MoFED, 2010).

\section{Methodology}

The study mainly emphasis on analysis of Ethiopian Central Statistical Agency (CSA) employmentunemployment statistical survey reported in 2018 with relevant literatures. After collecting of secondary data from this report, descriptive analysis was made based on the existing facts and figures to show the urban unemployment trend of Dire Dawa Administration. Further, additional secondary data from Ministry of Labor and Social Affairs as well as from Ministry of Finance and Economic Development has been collected to support the analysis process. However, the finding of the study is not sufficient to claim for all encompassing collection of data. 
In order to triangulate and supplement secondary data, the researcher conducted an interview through purposively selecting two experts at Dire Dawa Bureau of Finance and Economic Development. Even though the data collected in such a way doesn't help to arrive at conclusion, it is important to support the secondary data; see their perceptions/views on unemployment, the constraints of employment, the available employment opportunities and the interventions to be taken for creating job opportunities to reduce unemployment. The qualitative data generated from interviews was organized and analyzed qualitatively through content analysis. For this reason, the collected data from the informal discussion was translated from Amharic to English language. After reading all of the qualitative data, it was reviewed and organized to develop a general understanding of the data set. Then, through narrative description the result of the entire qualitative data was analyzed and interpreted. In so doing, the information generated from interview is integrated with the analysis of facts and figures of secondary data.

Table 1: Personal background (adapted from CSA 2018
\begin{tabular}{|l|l|}
\hline \multicolumn{1}{|c|}{ Percentage } \\
\hline Sex: & 35.8 \\
Male & 64.2 \\
Female & \\
\hline Marital status: & 39.5 \\
Never Married & 43.8 \\
Married & 7.3 \\
Divorced & 6 \\
Widowed & 3.4 \\
Separated & \\
Live together & \\
\hline Literacy status: & 83.4 \\
Literate & 16.6 \\
Illiterate & \\
\hline Work Experience: & 62.2 \\
With work experience & 37.8 \\
Without work experience & \\
\hline Training status: & 20.4 \\
Trained & 79.6 \\
Not trained & 16.4 \\
\hline Male & 32.6 \\
\hline Female &
\end{tabular}

\section{Results and discussion}

In terms of unemployment rate, Dire Dawa Administration has the highest urban unemployment rate in comparisons of all urban areas in Ethiopia. According to the Central Statistical Agency urban employment unemployment survey report (2018), unemployment rate of Dire Dawa Administrative is 25.3 percent followed by Tigray Region (21.5 percent), Addis Ababa City Administration (20.2 percent) and Amhara Region (19.7 percent) respectively while the lowest unemployment rate (7.2 percent) is reported from Benishangul-Gumuz region. The survey result also reveals that the urban unemployment rate at national level is 19.1 percent.

The majority of unemployed persons are female which accounts 64.2 percent while the male share is 35.2 percent. Around 43.8 percent of them are married and 39.5 percent have never married. The remaining respondent considered themselves as 'divorced' (7.3 percent), 'widowed' ( 6 percent)' and 'separated' (3.4 percent).

The survey shows the level of literacy in Dire Dawa Administration is 83.4 percent while the remaining 16.6 are considered as illiterate. In this survey, a person is considered to be literate if he or she can read and write; otherwise, considered to be illiterate.

Out of the total urban unemployed persons in Dire Dawa around 62.2 percent had work experience and 31.8 percent have no previous work experience prior to the survey date.

Similarly, the majority of urban unemployed persons (79.6 percent) in Dire Dawa Administration have not trained prior to the survey date while the remaining (20.4 percent) has got training prior to the survey date. According to CSA any sort of theoretical or practical training exercise provided in class or outside class rooms and that has awarded certificate or diploma is considered as training. 


\section{Approaching of searching jobs}

Table 2: Methods of seeking work (CSA, 2018)

\begin{tabular}{|l|l|}
\hline \multicolumn{1}{|c|}{ Steps taken to search for work } & Percent \\
\hline Searching vacancy advertising boards & 16.3 \\
Through news paper, radio and TV & 0.3 \\
I have unemployment card & 1.2 \\
Seeking assistance of friends, relatives, etc. & 16.5 \\
Trying to establish own enterprise & 9.7 \\
Direct application to employers & 1.3 \\
Checking at work sites & 14 \\
Browse through internet/ website & - \\
Others & 1.5 \\
Not seeking job & 39 \\
\hline Total & 100 \\
\hline
\end{tabular}

Respondents were asked what mechanisms used in searching of jobs. Accordingly, significant number of persons (16.5 percent) responded that in order to get a job they seek assistance of their friends, relatives, etc. Similarly, 16.3 percent respond that they search vacancy advertising boards, 14 percent checking at work sites and 9.7 percent trying to establish own enterprise. The remaining 5.8 persons search the job through news paper, radio and TV, unemployment card, direct application to employers and others mechanisms. Surprisingly, the highest unemployed person (39\%) doesn't seek any Job.

\section{Challenges of job creation}

Table 3: Types of work needed (CSA, 2018)

\begin{tabular}{|l|l|}
\hline Type of work seeking or available for & Percent \\
\hline Self-employment & 35.4 \\
Paid employment-private & $5.5 \%$ \\
Paid employment-government & $5.2 \%$ \\
Any available work & 53.5 \\
Others & 0.4 \\
\hline Total & 100 \\
\hline
\end{tabular}

As per the survey results appeared in table 2, the majority of unemployed about 53.3 percent were available to take up any kind of job followed by persons who sought or intended to establish own business ( 35.4 percent), while those who were looking for paid job in private institution accounted to be about 5.5 percent followed by 5.2 percent in government sector and the remaining other covers only 0.4 percent. The same pattern was observed for the two sexes.

Table 4: Challenges in establishing business (CSA, 2018)

\begin{tabular}{|l|l|}
\hline Types of problem faced to start own business & Percent \\
\hline I have No problem & 0.5 \\
Shortage of finance & 75.5 \\
Lack of training & 3.8 \\
Problem of working place/land & 5.6 \\
Lack of finance and training & 7.4 \\
Lack of working place \& finance & 3.4 \\
Lack/ absence of License & -- \\
Shortage/ Absence of equipment & -- \\
Lack of information & 0.5 \\
Lack of support from Household & -- \\
Don't know & -- \\
Others & 3.3 \\
\hline Total & 100 \\
\hline
\end{tabular}

If 35.4 percent of unemployed would like to self-employment why they are unemployed so far? This is because they faced many challenges not to start their own businesses. Among unemployed population those who attempt to establish their own business were asked to state what difficulties they have been faced. The great majority of unemployed (75.5 percent) persons replied that shortage of finance is the main barrier to not establish their own business. The next important reason is lack of finance in combination with training followed by lack of working place/land, lack of training, lack of working place in combination with finance accounted of 7.4 percent 5.6 percent, 3.8 percent and 3.4 percent respectively. 


\section{Effect of unemployment on the lives of unemployment}

Table 5: Major problems faced as due to unemployed

\begin{tabular}{|l|l|}
\hline Types of main problems faced due to jobless & Percent \\
\hline Decreased household/ personal income & $63.3 \%$ \\
Unable to cover household expense & $12.3 \%$ \\
Unable to send children to school /cover school expense/ & $1.2 \%$ \\
Family dissolution & $0.2 \%$ \\
Getting stress & 2.8 \\
Hopelessness & 2.8 \\
Exposed to differed addictions & 1.7 \\
Hunger and luck of clothing & 0.7 \\
Isolated from social Participation & 0.7 \\
Fed up looking for a job & 5.8 \\
Others & 4.4 \\
\hline Total & 100 \\
\hline
\end{tabular}

The unemployed of urban persons were asked the types of main problems faced due to jobless by giving various alternatives. Based on their response, 63.3 percent of them explained that decreased household/ personal income was the fundamental problem faced so far due to joblessness. And 12.3 percent replied that jobless challenge them unable cover household expenses. The other challenges the respondents mentioned due to joblessness were unable to send children to school /cover school expense/; family dissolution; hopelessness; exposed to different addictions; hunger and luck of clothing; isolated from social participation; fed up looking for a job; and others in all accounts not more than 25 percent

Table 6: Main reason not found job (CSA, 2018)

\begin{tabular}{|l|l|}
\hline \multicolumn{1}{|c|}{ Main reason for not found job } & Percent \\
\hline No work was found related to in my profession & $5.5 \%$ \\
Lack of job opportunity & $56.5 \%$ \\
Lack of Training & $12.4 \%$ \\
Lack of experience & $5.5 \%$ \\
Lack of vacancy advertisement & $1.7 \%$ \\
Introduction of modern system of work & $1.4 \%$ \\
In search for better job opportunity & $4.3 \%$ \\
Not to work at distant place & $1.4 \%$ \\
To alter the usual place of work & $0.5 \%$ \\
Low payment/ salary & $0.6 \%$ \\
Slack period & $4.2 \%$ \\
Off season & $0.8 \%$ \\
Inconvenience of working time & - \\
Unable to speak local language & - \\
Others & $5.2 \%$ \\
\hline \multicolumn{2}{|c|}{ Total } \\
\hline
\end{tabular}

If the joblessness suffers such problems in the personal lives of the unemployed persons and society at large, then what is main reason for not found Job? There are numerous obstacles that hinder the Dire Dawa Administration unemployed not found a job. Based on the survey, lack of job opportunity (56.5 percent) and lack of training ( 12.3 percent) takes the lion share followed by lack of experience ( 5.5 percent), lack of work related to the profession (5.5 percent) and other factors (5.2 percent) respectively. The rest of the respondents listed other hindrance factors that limit not to found jobs including, in search for better job opportunity (4.3 percent); slack period ( 4.2 percent), lack of vacancy advertisement (1.7 percent), introduction of modern system of work (1.4 percent), not to work at distant place ( 1.4 percent); off season $(0.8$ percent $)$, low payment/ salary (0.6 percent) and to alter the usual place of work ( 0.5 percent) respectively. However, all these factors cover only 15 percent of respondents. 


\section{Effect of unemployment on society}

Table 7: ways of getting support for their lives (CSA, 2018)
\begin{tabular}{|l|c|}
\hline Means of supporting their lives & Percent \\
\hline Casual Work & $3.1 \%$ \\
Family Support & $83.1 \%$ \\
Support from Relatives \& Friends & $5.9 \%$ \\
Saving & $1.7 \%$ \\
Remittance & $4.3 \%$ \\
Begging & $1.2 \%$ \\
Others & $1.7 \%$ \\
\hline Total & 100 \\
\hline
\end{tabular}

The survey tried to assess how unemployed persons are leading their live in such circumstances of unemployment condition. Accordingly, the highest number of persons (83.1 persons) replied that they are supported by their family followed by support from relatives $\&$ friends ( 5.9 percent) and remittance ( 4.3 percent). While the remaining unemployed explained as the get support from Casual Work (3.1percent) saving (1.7 percent), begging (1.2 percent) and others (1.7 percent). This implies that the significant numbers of unemployed persons are directly depending on the support of their family which, in turn, affects the economy of the country

\section{Conclusion and policy recommendation}

Urban unemployment is a major problem in Dire Dawa Administration which affects the societal lives in many ways. This study is conducted based on the 2018 CSA survey of employment- unemployment statistical report. Based on the report the urban unemployment rate Dire Dawa Administration is the highest in comparison of other urban areas of the country. The survey prevails that 64.2 percent of unemployed population are female while male unemployed accounts 35.8 percent. More than half (56.5 percent) of unemployed explained that lack of job opportunity is main reason for not found job followed by absence of work related with their profession and lack of vacancy advertisement. Majority of urban unemployed population want to work any available job which shares 53.2 percent. Surprisingly, 35 percent of unemployed prefer to be self-employed. However, lack of finance, lack of training \& finance and lack of working place are major challenges not start their own business. Decreased household/ personal income, unable to cover household expense and fed up looking job are major challenges they faced due to joblessness. Thus, the administration should focus on labour intensive investments that can employ huge man-power at a time. Besides the government should create suitable working environments for those who want to establish their own business including provision of financial credit without any collateral, working place and enhancing the skill levels of available labor force to match it with the skill that the economy requires with the collaboration of nearby higher institutions.

\section{Reference}

A. G. Blomqvist (2012) . Urban Job Creation and Unemployment in LDCs: Todaro Vs. Harris and Todaro. Workshop Paper.

Alhawarin, I., \& Kreishan, F. (2010). An analysis of long-term unemployment (ltu) in jordan's labor market. European Journal of Social Sciences, 15(1), 56-65.

B. Paul. Urban Unemployment in Developing Countries. Geneva: ILO, 2005.

Echebiri, R. (2005). Characteristics and determinants of urban youth unemployment in umuahia, nigeria: Implications for rural development and alternative labor market variables.

Economic Commission for Africa (ECA, 2005). Economic Report on Africa 2005 Meeting the Challenges of Unemployment and Poverty in Africa. ECA Publication Cluster, 2005.

Eita, J. H. and Ashipala, J. M. (2010). Determinants of Unemployment in Namibia. International Journal of Business and Management, 5(10), 92-104.

F.Nazir, M.A. Cheema, M.I.Zafar and Z. Batool. Socio-Econoic Impacts of Unemployment in Urban Faisalabad, Pakistan Journal of Socila Science, 18(3): 183-188. Department of Rural Sociology, University of Agriculture, Faisalabad 38040, Pakistan, 2009.

Getinet A. (2003) . The incidence of youth unemployment in urban Ethiopia. a paper presented at the 2nd EAF International Symposium on Contemporary Development Issues in Ethiopia, 11-13 Jul 2003, Addis Ababa, Ethiopia, 2003.

Hussmanns, R. (1989). Measurement of employment, unemployment and underemployment- Current international standards and issues in their application. Bulletin of Labour Statistics, ILO, Geneva, 1989-1

Kingdon, G., \& Knight, J. (2004). Unemployment in south Africa: The nature of the beast.Toit, R. (2003). Unemployed youth in south Africa: The distressed generation? Paper presented at the the Minnesota International Counseling Institute, Minnesota.

Mankiw, N. G. (2002). Macroeconomics 5 $5^{\text {th }}$ Edition. New York, NY: Worth, 2002. 
Mesfin, M (2012). Determinants of Women Unemployment in Ethiopia: A Multilevel Model Approach.Masters Thesis. Addis Ababa University, Addis Ababa, Ethiopia, 2012.

MOE (2006). National technical and vocational education and training strategy. Addis Ababa: Ministry of Education (MOE).

MoFED. (2006). Ethiopia: Building on progress a plan for accelerated and sustained development to end poverty (pasdep) (2005/06-2009/10). Addis Ababa: Ministry of Finance and Economic Development (MoFED).

MoFED. (2010). Growth and transformation plan (2010/11-2014/15). Addis Ababa: Ministry of Finance and Economic Development (MoFED).

MoLSA. (2009). National employment policy and strategy of Ethiopia. Addis Ababa: Ministry of Labour and Social Affairs (MoLSA).

N.H. Broussard and Tsegay, G. (2012). Youth Unemployment: Ethiopia Country Study International Growth Center, Working Paper 12, 2012.

Olsson, O. (2009). Essentials of Advanced Macroeconomic Theory.

P. Serneels (2004). The Nature of Unemployment in Ethiopia. CSAE WPS/2004-01, 2004.

Peace Nganwa Paul Mbaka Deribe Assefa2015 The Nature and Determinants of Urban Youth Unemployment in Ethiopia Vol.5 (.3)

Rafik, M., Ahmad, I., Ullah, A. and Khan, Z. (2010). Determinants of Unemployment: A Case Study of Pakistan Economy (1998-2008). Abasyn Journal of Social Sciences, 3(1)

Syson. Causes of Increasing Rate of Urban Unemployment Among the Youth the case study of Lubaga Division in Kampala District in Central Uganda. Between the ages of 14-35 years. A Research Report, Makerere University, 2011.

Tegegn, G., (2012) Socio-Demographic Determinants of Urban Unemployment: The Case of Addis Ababa. Ethiopian Journal of Development Research Vol.33, No.2, 2012. 